\title{
Customer Service Officers' Ethic at PT. Avia Jaya Indah (Business Partner) PT. CPI In Pekanbaru
}

\author{
Prihati, Elly Nielwaty \\ Universitas Lancang Kuning \\ e-mail: Prihati@unilak.ac.id
}

\begin{abstract}
This study aims to determine (1) How Ethics of the Customer Service Officers of PT. Avia Jaya Indah at PT. Chevron Pacific Indonesia, (2) Any obstacles in implementing Ethics in the Customer Service Officers of PT. Avia Jaya Indah at PT. Chevron Pacific Indonesia. This research method is qualitative research, after the data in the field are collected through observation, interviews and documentation, the data is clarified according to the type of data, then the data is analyzed qualitatively to describe or describe the factors that lead to the Customer Service Ethics of PT Avia Jaya Indah at PT. Chevron Pacific Indonesia in Pekanbaru is not running as it should. The results of this study indicate that (1) The overall ethics of customer service serving PT. Avia Jaya Indah is good enough and in accordance with the specified indicators, but there are still some shortcomings, such as still often found CSI employees have not used greeting generously, still often found employees who are dressed in uniform and harmonious and there are still employees who are less professional in responding to work due to lack of information and understanding of Customer Service Officers on going work in the field. (2) Obstacles that occur in implementing service ethics at PT. Avia Jaya indah is that there is still lack of professionalism in communication with customers, no follow-up regarding follow-up of requests to the customer concerned, lack of Customer Service knowledge about work in progress in the field and lack of daily evaluations of supervisor work results of customer service employees.
\end{abstract}

Keywords: Customer Service, Service Ethics, Serving

\section{Abstrak}

Penelitian ini bertujuan untuk mengetahui (1) Bagaimana Etika dalam pelayanan Customer Service PT. Avia Jaya Indah pada PT. Chevron Pasific Indonesia, (2) Hambatan Apa saja dalam pelaksanaan Etika dalam pelayanan Customer Service PT. Avia Jaya Indah pada PT. Chevron Pasific Indonesia. Metode Penelitian ini adalah penelitian Kualitatif, Setelah data di lapangan terkumpul melalui proses obervasi,wawancara dan dokumentasi maka data tersebut penulis klarifikasikan sesuai dengan jenis data, kemudian data dianalisis secara kualitatif untuk mendeskripsikan atau menggambarkan faktor- faktor yang menyebabakan Etika Pelayanan Customer Servie PT Avia Jaya Indah pada PT. Chevron Pacific Indonesia di Pekanbaru tidak berjalan sebagaimana mestinya. Hasil dari penelitian ini menunjukkan bahwa (1) Secara keseluruhan etika pelayaanan Customer Servive PT. Avia Jaya Indah sudah cukup baik dan sesuai dengan indikator yang ditentukan namun masih ada beberapa kekurangan seperti masih kerap ditemukan karyawan Customer Service belum menggunakan greeting secara kesulurahan, masih kerap dijumpai karyawan yang berpakaian belum seragam dan selaras serta masih ada karyawan yang kurang profesional dalam merespon pekerjaan dikarenakan minimnya informasi dan pemahaman Customer Service terhadap pekerjaan yang sedang berlangsung di lapangan. (2) Hambatan yang terjadi dalam pelaksanaan etika pelayanan di PT. Avia Jaya indah yaitu masih terdapat kurang profesionalisme dalam komunikasi dengan customer, belum adanya tindak lanjutan dari permintaan kepada customer bersangkutan

Kata Kunci : Customer Service, Etika Pelayanan, Melayani 


\section{INTRODUCTION}

Public service outonomy local region was determined as the indicator of the success of local region autonomy implementation. In the other words, if the public service implemented by the government has a certain quality, so the implementation of region autonomy will bee success because the quality of public service is supported by the administration paradigm changing.

The linkage of public administration and business administration can be described from the strong criticism of low respon of public sector performance. It causes experts to initiate the public service sector changing to be better and more efficient. I can be said that public service implementation is weaker than business administration.

Recently, there are two paradigms competing to replace the Old Public Administration Public (OPA). First, new Public Management (NPM) model which focus on the internal government management improvement. It used the superior private sector ideas in creating the customer oriented service. Second, New Public Service (NPS) model which focus on the public service implementation with citizen oriented as the owner of the public service. NPM has tried to insert business administration standard into the public organization so it produces good performance. NPS model give a solution by keeping attention to the public organization characteristics while improving public administration performance pragmatically.

Nowadays, the term state administration changed into public administration. In the public administrative science, the concept of public has broad meaning. It cannot be defined as government (only) but also non-government organization, association, and private organization. So, fairness, patriotism, citizenship responsiveness, and ethic are the important aspects as well as efficient and effectiveness values.

P.T Chevron Pasific Indonesia (CPI) is one of government partner with contribution focus on oil exploration in Riau Province since 1942. This partnership program has improved Indonesian people's earning. It donated about US\$ 200 Billion to country revenue. P.T CPI (formerly Caltex Pasific Indonesia) has been operated in Indonesia since 50'. It operated in several regions in Indonedia. It significantly improved Indonesian Oil and Gas production. There are the regions where Chevron takes place in Indonesia:

1. Rokan in Rokan Hilir Regency

2. Cepu in Bojonegoro and Sampang Regency, Madura Island, East Java

3. Mahakam in offshore of Kutai Kertanegara Regency

4. Offshore of Bekasi Regency, Karawang, Subang and Indramayu, West Java

5. Jakarta Bay

6. Riau Island

7. Teluk Bintuni Bay and Fak-Fak Regency in West Papua

8. Musi Regency and Banyuasi, East Sumatera

9. Banggai Regency, Central Sulawesi

10. West and Eeast of Jabung Regency, Jambi

Nowadays, the employees of CPI are located in four cities in Riau, they are Dumai (shipping), Duri (Exploration), Minas (Exploration), and Rumbai (Administration). CPI is the biggest oil company in Indonesia, with 2 billion barrels production. CPI cooperates with government and other companies to create double economical effect from the oil exploration in Indonesia. This oil production program donated Rp. 455 trillion for Indonesian government revenue. In 2013, Chevron and mitra donated Rp. 120 trillion to Iindonesian revenue. Therefore, improving the CPI employees indirectly will improve the country revenue. So, one of the way is by improving the employees' comfortable and easiness in doing 
the activities. Finaly, it is need to provide a work partner to assist all the CPI employees' activities such as PT. Avia Jaya Indah as service providing company.

PT. CPI will finish the official partnership with Indonesia in 2021 and there is no decision to continue it yet. It is strengthened by the statement of Ministry of Energy and Mineral Resources which says that PT. Pertamina (Persero) will be the new contractor of Riau Working Area. So, the transfer of private sector into public sector will be a benchmark for the quality of service ethic.

The large and spread operating area of PT. CPI requires a capable media to keep both internal and external communication. It needs helpdesks called Customer Sevice Integreted (CSI) for sharing information about the activities within the company. This CSI officers has been providing by PT. Avia Jaya which are located in Rumbai, Pekanbaru district, Minas/Petapahan, Duri, Dumai, and Jakarta.

PT. Avia Jaya which is centered in Jakarta is a service company with focus on airframe cleaning, cleaning service provision in malls, and customer service officers. PT. Avia Jaya aims at assisting PT. $\mathrm{CPI}$ in establishing the management facilities service and assests administration management of PT. CPI. Based on the above phenomenon, the researcher focuses the study on the management facilities service of PT. CPI assisted by PT. Avia Jaya in Rumbai district.

There will be problem comes in providing service as well as customers' inconveniences caused by the customer service officers' attitude. Otherwise, the customer service officers assumed that he / she provide a service well. It means that there is a missunderstanding between them. The problems can be from the customer service officers' politeness in asking question and disrespectfully dressed. They may come from the customer service officers' lack of ethics.

One of PT. Avia Jaya punishments for the CSI officers who break the rules is having warning letter sent via email. If the customer service officer has no mistakens for three months, they will get rewards from PT. Avia Jaya indah in salary bonus. This program of reward and punsihments aims to motivate the employee in doing the job.

Generaly, ethics defined as procedure in keeping connect to other people. The procedure of each society or customer is diverse. It is caused by the various culture of society which comes from various areas, tribes, religons, and customs. This procedure is very crucial in human life in order to keep the harmonious relationship and respecfullness each others. Practicaly, ethic is very important to show in formal situation.

Ethic performance in implementation of service needs human resources as well as a reliable employee because she/he will serve the customer directly. That is why the human resources should be improved. One of the ways to improve the customer service officers' ethics is by giving guiding and training about how important ethic must be in service providing. A good and right service is an effort to give satisfaction, convenience, and trust developing to customers.

Sadu Wasistiono in Hardiyansyah says that Public service is a service provided by either governement or private company to the community either in free or in charge to fulfill the public needs. Service ethic is a way in communicating to customers. In the other words, it needs a particular operational procedure implementation in providing a service to satisfy the customer. If the customers satisfy and feel happy, they will affect the success of transaction between customers and employee at this time and in the future.

Manager should monitor and improve the customer service integreted officers' ethics in order to avoid the bad service implementation. This bad service implementation will decrease the customers' trust to the bussiness run by the management.

Service ethics is determined by the moral quality of the company management. Commitment, integrity, and accountability of the company management in providing the qualified service will be the power to run the quality ethical service function. Managers should be aware of the front line officers as their representative in providing the ethical service. This managers' awareness is formed of policy, 
attitude, behaviour, decision, and continuously service improvement. Besides that, managers should have emphaty and responsibility to keep and improve the front line officers' attitude.

Customer service integreted officers serving is an activity done to satisfy the customers. The service also contains of complaint or trouble faced by the cutomers. So, CSI officers must be able to find out the solutions for solving the customers' problems.

CSI officers' service is not only given to the customers out of the company, but also given to the internal employee and employees' family. So, the employees' performance will be maximum and efficient towards the company demands. PT. Avia Jaya Indah is one of the profesional service providers which is oficially used by PT. CPI in implementing service. It will assist PT. CPI works especially in maintenance and service. So, customer service officers have a crucial role in connecting the customers of PT. CPI with the Business Partner (BP).

PT. Avia Jaya Indah has been operating since 32 years ago at Street of Husein Sastranegara in Tangerang district. It focuses on airframe cleaning, airport, janitor, service, outdoor service, and helpdesk service. This reseacrh limited to the helpdesk service of PT. Avia Jaya Indah in PT. CPI, Rumbai district.

CSI of PT. Avia Jaya Indah in PT. CPI Pekanbaru has been actively operating since 2014 to 2019. Along this term, the employee's performance has been evaluated by service users such as internal customers, external customers, and all the employee of PT. CPI. That is why PT. Avia Jaya Indah monitors the employees' performance especially the ethic of customer service officers periodically. 2018.

This following table shows us the evaluation of Customer Service Ovicers of PT. Avia Jaya Indah in

Tabel I.1: CSI Officers' Performance Evaluation of PT Avia Jaya Indah in Pekanbaru

\begin{tabular}{|c|c|c|c|c|c|c|c|c|c|c|c|c|}
\hline \multirow[b]{2}{*}{ NO } & \multirow[b]{2}{*}{ NAME } & \multicolumn{11}{|c|}{ ACTIVITIES } \\
\hline & & $\begin{array}{c}\text { NON- } \\
\text { ONTIME }\end{array}$ & EMAIL & $\begin{array}{c}\text { INPUT } \\
\text { COMMIT }\end{array}$ & $\begin{array}{l}\text { DISPATCH } \\
\text { COMMIT }\end{array}$ & $\begin{array}{l}\text { OPEN } \\
\text { F.139 }\end{array}$ & $\begin{array}{l}\text { CLOSE } \\
\text { F.139 }\end{array}$ & vow & $\begin{array}{c}\text { FOLLOW } \\
\text { UP }\end{array}$ & $\begin{array}{c}\text { CLOSE } \\
\text { COMMIT }\end{array}$ & $\begin{array}{l}\text { UPDATE } \\
\text { COMMIT }\end{array}$ & INACCURATE \\
\hline 1 & Febriyanti & $0,0 \%$ & $13,2 \%$ & $8,1 \%$ & $8,1 \%$ & $0,0 \%$ & $0,0 \%$ & $0,0 \%$ & $8,1 \%$ & $0,0 \%$ & $0,0 \%$ & $0,0 \%$ \\
\hline 2 & Sisma Rinelva & $0,0 \%$ & $9,6 \%$ & $8,5 \%$ & $8,5 \%$ & $0,0 \%$ & $0,0 \%$ & $0,0 \%$ & $8,5 \%$ & $0,0 \%$ & $0,0 \%$ & $0,0 \%$ \\
\hline 3 & Yunessya Rizal & $9,1 \%$ & $15,1 \%$ & $6,6 \%$ & $6,6 \%$ & $0,0 \%$ & $0,0 \%$ & $0,0 \%$ & $6,6 \%$ & $66,5 \%$ & $52,6 \%$ & $0,1 \%$ \\
\hline 4 & Novianti Herawati & $4,5 \%$ & $10,4 \%$ & $3,0 \%$ & $3,0 \%$ & $55,4 \%$ & $52,7 \%$ & $95,9 \%$ & $3,0 \%$ & $0,0 \%$ & $0,0 \%$ & $0,0 \%$ \\
\hline 5 & Anisha Agustia & $0,0 \%$ & $0,0 \%$ & $6,4 \%$ & $6,4 \%$ & $0,0 \%$ & $0,0 \%$ & $0,0 \%$ & $6,4 \%$ & $0,0 \%$ & $0,0 \%$ & $0,0 \%$ \\
\hline 6 & Mitra Oktavia & $0,0 \%$ & $1,3 \%$ & $11,3 \%$ & $11,3 \%$ & $0,0 \%$ & $0,0 \%$ & $0,0 \%$ & $11,3 \%$ & $0,0 \%$ & $0,0 \%$ & $0,0 \%$ \\
\hline 7 & Emil Budiutomo & $9,1 \%$ & $0,0 \%$ & $4,5 \%$ & $4,5 \%$ & $0,0 \%$ & $0,0 \%$ & $0,0 \%$ & $4,5 \%$ & $0,0 \%$ & $0,0 \%$ & $0,0 \%$ \\
\hline 8 & Laura Soraya & $13,6 \%$ & $10,0 \%$ & $1,6 \%$ & $1,6 \%$ & $44,6 \%$ & $47,3 \%$ & $4,1 \%$ & $1,6 \%$ & $0,0 \%$ & $0,0 \%$ & $0,0 \%$ \\
\hline 9 & Herman Soesilo & $0,0 \%$ & $20,1 \%$ & $4,7 \%$ & $4,7 \%$ & $0,0 \%$ & $0,0 \%$ & $0,0 \%$ & $4,7 \%$ & $33,5 \%$ & $47,4 \%$ & $0,0 \%$ \\
\hline 10 & Rory Pratiwi & $0,0 \%$ & $1,7 \%$ & $11,9 \%$ & $11,9 \%$ & $0,0 \%$ & $0,0 \%$ & $0,0 \%$ & $11,9 \%$ & $0,0 \%$ & $0,0 \%$ & $0,0 \%$ \\
\hline 11 & Nadi & $0,0 \%$ & $5,1 \%$ & $8,2 \%$ & $8,2 \%$ & $0,0 \%$ & $0,0 \%$ & $0,0 \%$ & $8,2 \%$ & $0,0 \%$ & $0,0 \%$ & $0,0 \%$ \\
\hline 12 & ML. Tambunan & $0,0 \%$ & $3,7 \%$ & $8,4 \%$ & $8,4 \%$ & $0,0 \%$ & $0,0 \%$ & $0,0 \%$ & $8,4 \%$ & $0,0 \%$ & $0,0 \%$ & $0,0 \%$ \\
\hline 13 & Abdul Kholidin & $0,0 \%$ & $1,2 \%$ & $6,2 \%$ & $6,2 \%$ & $0,0 \%$ & $0,0 \%$ & $0,0 \%$ & $6,0 \%$ & $0,0 \%$ & $0,0 \%$ & $0,1 \%$ \\
\hline & TOTAL & $2,8 \%$ & $100 \%$ & $89 \%$ & $89 \%$ & $100 \%$ & $100 \%$ & $100 \%$ & $89 \%$ & $100 \%$ & $100 \%$ & $0,3 \%$ \\
\hline
\end{tabular}

Data Source: Summary of Activities Percentage of PT. Avia Jaya Indah, 2018

The table describes that there is a low percentage of working standard in giving service in 2018 . The evaluation was done four times in a year. It aims at giving a guidance of particular and structural Standard Operational Procedure (SOP) and minimalizing the mistaken in data input to system of PT. CPI.

Besides that, PT Avia Jaya Indah has a clear flow chart in the process of service implementation. It eased other companies to manage administration compiling in helpdesk. There are several companies worked together in facility management of PT. CPI.

PT. Asia Jaya Indah customer service integrated is a center of companies and PT. CPI assets administration compiling. CSI officers must be careful in order to minimalize mistaken and avoid disadvantages. 
Facility management is a program of PT. CPI in serving residents in PT. CPI camp. Furthermore, PT. CPI has many partners for assisting its' working program. So that is why PT. Avia Jaya Indah was decided as the front liner and accommodates other companies to manage the facilities at PT. CPI. This following table shows the list of work partner companies within management facility of PT. CPI.

Table I.2 : List of Work Partner Companies within South Facility Management

\begin{tabular}{|c|c|c|c|c|}
\hline NO & $\begin{array}{c}\text { BUSINESS } \\
\text { PARTNER / PT }\end{array}$ & TIME OF JOINNING & JOB DESCRIPTION & NOTE \\
\hline 1 & $\begin{array}{l}\text { PT AVIA JAYA } \\
\text { INDAH }\end{array}$ & $\begin{array}{l}1 \text { November } 2014 \text { - } 31 \\
\text { October } 2019\end{array}$ & $\begin{array}{l}\text { Customer Service } \\
\text { Integreted }\end{array}$ & Active \\
\hline 2 & $\begin{array}{l}\text { PT. SURYA } \\
\text { MULIAGITA } \\
\text { GRAHA (SMGG) } \\
\end{array}$ & $\begin{array}{l}15 \text { June } 2015-14 \\
\text { June } 2019\end{array}$ & $\begin{array}{l}\text { Corrective } \\
\text { Civil/Plumbing Office } \\
\text { and Housing }\end{array}$ & Active \\
\hline 3 & $\begin{array}{l}\text { PT PURICINDO } \\
\text { KARYA } \\
\text { PERDANA }\end{array}$ & $\begin{array}{l}\text { 1 July } 2015-30 \text { June } \\
2018\end{array}$ & $\begin{array}{l}\text { Matrass Loundry and } \\
\text { Goods Purchasing }\end{array}$ & Innactive \\
\hline 4 & PT. INDOCATER & $\begin{array}{l}28 \text { December } 2015 \text { - } \\
22 \text { January } 2022\end{array}$ & $\begin{array}{l}\text { Recreation, Event } \\
\text { Organizer, Banner and } \\
\text { Billboards Printing }\end{array}$ & Active \\
\hline 5 & $\begin{array}{l}\text { CONSORTIUM PT. } \\
\text { MAS MURNI } \\
\text { INDONESIA \& PT. } \\
\text { BUMI SINAR } \\
\text { BELLA } \\
\end{array}$ & $\begin{array}{l}13 \text { February } 2016- \\
12 \text { February } 2019\end{array}$ & Accomodation & Active \\
\hline 6 & $\begin{array}{l}\text { PT TRITUNGGAL } \\
\text { SEJAHTERA } \\
\text { MARGAWI }\end{array}$ & $\begin{array}{l}1 \text { April 2016-31 } \\
\text { March } 2022\end{array}$ & $\begin{array}{l}\text { Good Moving, Housing } \\
\text { and office }\end{array}$ & Active \\
\hline 7 & $\begin{array}{l}\text { PT. POS } \\
\text { INDONESIA }\end{array}$ & $\begin{array}{l}\text { 1 June } 2016-31 \\
\text { May } 2019\end{array}$ & Letter and Good Delivery & Active \\
\hline 8 & $\begin{array}{l}\text { PT. ANGSA EMAS } \\
\text { PERDANA }\end{array}$ & $\begin{array}{l}4 \text { December } 2016-4 \\
\text { May } 2019\end{array}$ & Food Service & Active \\
\hline 9 & PT. SUCOFINDO & $\begin{array}{l}\text { 1 February } 2016-31 \\
\text { January } 2019\end{array}$ & Pest control & Active \\
\hline 10 & $\begin{array}{l}\text { PT. REZEKI } \\
\text { SURYA } \\
\text { INTIMAKMUR }\end{array}$ & $\begin{array}{l}\text { 1 January } 2016-31 \\
\text { May } 2020\end{array}$ & $\begin{array}{l}\text { Maintenance Preventive, } \\
\text { Corrective (Civil, } \\
\text { plumbing Listrik, } \\
\text { Mechanical) }\end{array}$ & Active \\
\hline 11 & $\begin{array}{l}\text { PT. JOSUA } \\
\text { BERSAUDARA } \\
\text { SAROHA }\end{array}$ & $\begin{array}{l}15 \text { May } 2016-15 \\
\text { May } 2023\end{array}$ & AC Maintenance & Active \\
\hline 12 & $\begin{array}{l}\text { PT. SWADAYA } \\
\text { ABDI } \\
\text { MANUNGGAL }\end{array}$ & $\begin{array}{l}\text { 1 June } 2018 \text { - } 31 \text { July } \\
2021\end{array}$ & $\begin{array}{l}\text { Maintenance Preventive, } \\
\text { Corrective (Civil, } \\
\text { electrical plumbing, } \\
\text { Mechanical) }\end{array}$ & Active \\
\hline 13 & $\begin{array}{l}\text { PT. GREEN } \\
\text { PLANET }\end{array}$ & $\begin{array}{l}4 \text { June } 2016-3 \\
\text { January } 2019\end{array}$ & Office Waste & Active \\
\hline
\end{tabular}




\begin{tabular}{|c|c|c|c|c|}
\hline 14 & $\begin{array}{l}\text { PT. LABINDO } \\
\text { YOS JAYA }\end{array}$ & $\begin{array}{l}1 \text { August } 2017-30 \\
\text { November } 2020\end{array}$ & WTP Machine Service & Active \\
\hline 15 & $\begin{array}{l}\text { PT. RIFANSIDWI } \\
\text { PUTRA }\end{array}$ & $\begin{array}{l}19 \text { September } 2016- \\
18 \text { September } 2019\end{array}$ & Office Waste & Active \\
\hline
\end{tabular}

Data Source: Analysis of PT. Chevron Pacific Indonesia, 2019

PT. Avia Jaya Indah set excellent service which focus on the ethic of customer service officers. Ethic has an important role in leading the work flow. Ethic aims at implementing a good and ethical work to gain the long-term success of business. In this case, helpdesk and customer service officer is the spearheaded of the service implementation. The following table presents the form of services of PT. Avia Jaya Indah for employee and residents at PT. CPI.

Table I.3: PT Avia Jaya Indah Service Implementation Forms for Employees and Residents of Housing at PT.CPI in Rumbai, Pekanbaru

\begin{tabular}{|c|c|c|}
\hline NO & CUSTOMER SERVICE & DATA ANALYST \\
\hline 1 & $\begin{array}{l}\text { Receiving complaints from } \\
\text { customers related to facility } \\
\text { management via: } \\
\text { - Email } \\
\text { - Telephone } \\
\text { - Oral request } \\
\text { - SMS }\end{array}$ & $\begin{array}{l}\text { Receiving Work Order from work } \\
\text { partners or CSI officers such as } \\
\text { document F-139 and VOW } \\
\text { (Verification Of Work) via: } \\
\text { - Email } \\
\text { - Telphone }\end{array}$ \\
\hline 2 & $\begin{array}{l}\text { Connector among costumers, } \\
\text { work partners, and personal In } \\
\text { chars. }\end{array}$ & $\begin{array}{l}\text { F-139 Document Recording into JDE } \\
\text { System. }\end{array}$ \\
\hline 3 & $\begin{array}{l}\text { F-139 dokument inputing and } \\
\text { VOW from partner working } \\
\text { companies under FM into system. }\end{array}$ & $\begin{array}{l}\text { Document arrangement process to } \\
\text { ARIBA }\end{array}$ \\
\hline 4 & $\begin{array}{l}\text { Sharing information to the } \\
\text { customers of PT. CPI and } \\
\text { business partners related to } \\
\text { facility management and assests } \\
\text { of PT. CPI. }\end{array}$ & $\begin{array}{l}\text { Budget inputing from each working } \\
\text { partners company of facility } \\
\text { management of PT. CPI. }\end{array}$ \\
\hline 5 & $\begin{array}{l}\text { Committee of room loan of PT. } \\
\text { CPI for event organizing. }\end{array}$ & $\begin{array}{l}\text { Assisting PT. CPI employee in } \\
\text { applying the system of company } \\
\text { budgeting and other problems. }\end{array}$ \\
\hline
\end{tabular}

Data Source : PT. Chevron Pacific Indonesia distric Rumbai, 2019

Costumer service officers' ethic will positively affect the customers' conveniences concerning to their request which has been not handled yet. To implement the well-organized service, there must be a regulation applied. It will support all the components of service implementation run effectively and efficiently. In the other words, there should be an ethic standardization of service implementation used.

Practically, PT. Avia Jaya Indah has been implementing a general standard in case of communication ethic to the customers based on the Standard Operational Procedure of Customer Service area of PT. Avia Jaya Indah Facility Management. They are as follows: 
1. Greeting and offering a help.

2. Inviting guest to come and sit politely.

3. Asking customers' needs.

4. Apologizing and asking help to customers

5. Expressing grateful to customers and offering more help.

Employee should concern to PT. Avia Jaya Indah regulation to support the optimal service implementation. Those above service implementation ethics is not difficult to practice. In fact, there is still obstacle found by the CSI officers. In conclusion, almost all of employees of PT. Avia Jaya Indah did not run the regulation well.

The general problems faced by the CSI officers were they did not used to greet the customers in phone call as well as informal situation. It was proved by a complaint from PT. CPI Supervisor on PT Avia Jaya Indah. It supported PT. Avia Jaya Indah to improve the CSI officers' ethic especially in Facility Management sector.

Customer service aims at giving satisfaction to customers in solving the problems through qualified service implementation. The service implementation consisted of receiving the complaints or troubles. For achieving a qualified service, CSI officers must be right on the target and using formal language in responding email or phone call. So, the customers feel convenience and believe in the service implementation. In fact, there were employees of PT. Avia Jaya Indah still got wrong in delivering the message.

\section{METHOD}

After collecting the data through observation, interview, and documentation, the researcher clarified them based on the data types. Then, they were analyzed qualitatively to describe the factors influenced the customer service integrated officers' ethic of PT. Avia Jaya Indah on PT. CPI in Pekanbaru did not run as it was.

\section{FINDING AND DISCUSSION}

According to Kasmir, customer service officers' ethic has several indicators which can be references in customer service implementation standardization in an institution or company. The indicators contains of attitude, behavior, performance, dressing, way of talk, gestures, and asking questions.

An ethical service is absolutely needed to support a harmonic working relationship in an institution. So, the main goal of the company can be achieved optimally. So that the customer service integreted officers' ethic of PT. Avia Jaya Indah as the work partner of PT. CPI Pekanbaru.

This ethic of CSI officers of PT Avia Jaya Indah as the work partner of PT. CPI Pekanbaru will be discussed based on the above indicators.

Customer Service Integrated (CSI) officers' ethic of PT. Avia Jaya Indah (the work partner of) PT. CPI Pekanbaru.

\section{Attitude and behaviour}

Attitude and behaviour refers to someone's action in facing someone else in daily life. A well attitude and behaviour is very important in ethical service implementation and it must be in employees themselves. 
A good image presented by CSI officers will influences the customers' first impression in doing interaction with them. Hospitality given to the customers is the basic reference of attitude and behaviour evaluation of PT. Avia Jaya Indah's CSI officers. The evaluation consists of hospitality, responsibility, and politeness of officers in implementing the service.

a. Hospitality and Politeness

Hospitality is an attitude and behaviour of society in association such as smile, politeness, and respectful in communicating. Politeness relates to the cultural values of society. It is different in each group of societies.

This following script is the interview result based on indicator hospitality and politeness with Mrs. Erisma who lives in Camp. Palem of PT. CPI, No. 306.

"Selama yang sudah kita jalani selama saya tinggal dirumbai ini kurang lebih selama tiga tahun, itu sangat bagus sekali, setiap saya menelepon ke helpdesk,. Dari segi tanggung jawab bagus, setiap ada kendala selalu cepat ditindak lanjuti, belum pernah ada keluhan. "(Interview result with the resident of Camp CPI Palem 306, $22^{\text {nd }}$ of June, 2019, time: 10.06 a.m)

Interviewee stated that as long as she lived in Palem 306, customer service officers had a good hospitality. They communicate well and the customers had no complaint about it.

Then, below is an interview result from Bapak Beno Pramudya who lives in Camp Hibrida, 121.

"menurut saya untuk keramah tamahannya sudah sangat bagus,mereka waktu angkat telpon memperkenalkan nama,nomor badge, apa yang direquest jadi dalam keramah tamahan menurut saya sudah bagus, dan sopan santun sudah baik tidak ada pertanyaan yang tidak patut atau tanggapan yang tidak layak tidak pernah saya temui" (Interview result with the resident of Camp CPI Hhibrida 121, 28 of June, 2019, 01.53 p.m).

From the result of interview, it can be said that the customer service officers' hospitality was very good. The communication begins with asking about the customers' complaint and customers' identity.

Based on the result of interview on employees' hospitality, it was found that PT. Avia Jaya Indah employees have a good hospitality and politeness. It was proved by the family atmosphere in the office among the employees of business partners, PT. CPI, PT. Avia Jaya Indah, and residents of PT. CPI Camp. It was consisted in the Standard Operating Procedure of PT. Avia Jaya Indah relates to procedure of starting the job and procedure of doing the job (SOP CSI-01/FMN No. 02, Revisi II).

b. Responsibility

Responsibility is a compulsory requirement acted by someone to endure an action done by himself/herself in conscious or not. It means, take all the responsibility and completing all job based on the job description. PT. Avia Jaya Indah has responsibility to take over all the process of coming request from the beginning to the finishing.

The researcher found that there were no routines schedule of CSI officers to follow up the request reported to particular team. So, customers often think that their requests were not processed by the CSI officers. It can be proved by following interview result.

"Kayaknya masih banyak kendala mbak ya, misalnya untuk ganti - ganti lampu, ganti gantiganti kompor, kayakya masih lama ya, bisa dua mingguan lah ya. Harusnya untuk penggantian kecil seperti itu bisa hanya satu hari saja prosesnya." (Interviewe result from Mrs. Nila Yolanda, the resident of Kenari Camp. No. 123, $2^{\text {st }}$ of June, 2019, time: 01:07 p.m).

From the above interview result, there is a complaint towards the customers' request to CSI officers. The customer felt that the respond given is too late. They need too long time to process insignificant request such as changing a light.

Goes along with it, Mr. Beno Pramudya, the resident of Hibrida Camp No. 121, says a similar idea about the CSI officers' responsibility in processing the request. 
"Untuk penangan pertama itu bagus, cepat tanggap, Cuma follow up-nya yang beberapa kali saya lihat itu kurang, misalnya mungkin mereka sudah forward ke team terkait tapi kalau belum dilaksankan itu tidak ada follow up lagi, harusnya ada feed back lagi. (Interviewe result from Resident of Hibrida Camp No. 121, $28^{\text {th }}$ of June, 2019, time: 01.53 p.m).

It can be said that there was a quick response given by the customer service officers toward the request, but there was no follow up relates to the process of request fulfilment. It makes the customers assume that the customer service officers have lack of responsibility in administering the requests.

The researcher also found the similar complaint from an employee of PT. CPI at South Office namely Mr. Beno Ibrahim.

"Kalau kendala pasti ada, kendala itu kan sifatnya karena kawan kawan di CSI- inikan sifatnya menghubungkan kita ke pihak - pihak terkait, jadi pihak pihak terkait ini yang tidak bisa kita kontrol, jadi kami juga memahami dalam pelaksanaannya kadang - kadang mengalami keterlambatan atau ada yang tidak sesuai" (Interview result from Mr. Beno Ibrahim, the employee of PT. CPI, $21^{\text {st }}$ of june, 2019, time: 01.53 p.m).

The data says that the CSI officers were too late in administering the customers' requests because of the field constraints such as material, field condition, and related team. Then, the researcher found that the request was too late to administer because of human error aspect on the customer service officers.

In conclusion, the standard operational procedure is well organized even though several complaints come from the Camp residents related to the time consumed in processing a complaint because the CSI officers were just the connector between the residents and the related parties. There was also a human error on the CSI officers related to inputting request into the system. They sometimes delay it in few minutes, so the process delivery of request became late. In general, the CSI officers had good politeness and hospitality even though there were several complaints from the customers. In fact, it caused by the customers' misunderstanding on the customer service officers' work flow.

\section{Performance}

Performance is a way of employees to dress, wear accessories, behave, and communicate. They will present the harmonious relationship between their selves and work environment. Performance is divided into two groups; physic, and non-physic. Non-physically performance in this research is determined by the employees' behaviour. After observing and analysing the data, the researcher found that the customer service officers were well-behaved because they had got training related to qualified service implementing standardization.

There are several interview result relates to the employees' performance presented to support the data.

"Mungkin untuk pakaian sudah aturan dari perusahaan CSI, mungkin untuk riasan yang menyolok mungkin harus dikurangi kalo dapat dihilangkan demi keselamatan kalau pulang kerja, untuk sabtu minggu sering nampak tidak pake seragam." (Interviewe result from Mr. Anto, $\mathbf{1 7}^{\text {th }}$ of June, 2019, time: 08.23 a.m).

It can be known that the CSI officers were well-dressed and suitable to the regulation. Interviewee also suggested the customer service officer to not make-up lightly. Then, it was also found that there were some of them wear unformal uniform. They wore casual fashion and looked untidy. Based on the regulation, PT. Avia Jaya Indah allowed the employees for formal free dressing such as shirt and shoes. But they cannot be allowed to wear T-Shirt and sleepers. 
Overall, the CSI officers' performance was good and appropriated with the SOP No.CSI-01/FMN No. 2 about procedure of starting the work. Unfortunately, it was still found that there were some employees wore untidy and casual fashion.

\section{Dressing}

It refers to how the way people wear the clothes and how the things sthick to his/her body such as shirt, pants, shoes, and accessories in particular time (in working area). In this case, dressing relates to the emploeess' uniform.

The researcher found that CSI officers' outfit was regulated by PT. Avia Jaya Indah. They must wear the uniform based on the day. The results of interview below are presented to support the data.

"Sebagian masih ada yang tidak memakai seragam lengkap Cuma masih ada beberapa yang tidak menggunkan seragam dengan teman yang lain, mungkin karena CSI baru atau mungkin sedang hamil tidak memakai sergam lagi, jadi untuk seragam cukup bagus namun masih harus ditingkatkan lagi dalam keseragamannya." (Interviewe result from Mr. Trikorades, the employee of PT. CPI, 19 ${ }^{\text {th }}$ of June, 2019, time: 12.12 p.m).

From interview result above, it can be seen that there were some new and pregnant CSI officers did not wear the uniform. So, it is need to increase the awareness of wearing uniform.

This is the interview result from one of business partner employees who routinously visits and interacts with the customer service officers.

"Untuk keseragaman CSI sudah sesuai namun alangkah lebih baiknya jika jilbab juga diseragamkan juga, jika senada akan lebih kompak." (Interviewe result from one of busniness partner employees of PT. RSIM, $20^{\text {th }}$ of June, 2019, time: 10.21 a.m). uniform.

In this case, the interviewee suggested the CSI officers to wear veil which has similar colour to the

Based on the data, there were some employees did not wear uniform determined by PT. Avia Jaya Indah due to uniform impropriety such as tight and torn. In conclusion, the way of dressing had been determined by PT. Avia Jaya Indah. Based on the researcher's observation, the CSI officers generaly have been well-dressed even though there were some of them did not wear the uniform, similar colour of veil, and standard shoes. Besides that, PT. Avia Jaya Indah was late to renewal the uniform. It was scheduled annually. But, it usualy delayed few months later. It can be proved by photo documentation collected by the researcher.

\section{Way of Talking}

Way of talking refers to someone's style in expressing and describing something to customers either face to face or via telephone. A good way of talking must absolutely had by all the customer service officers because it is important in delivering message to be responded quickly.

Every customer service officers had trained based on the procedure. Generaly, they have qualified ability in communicating. This following interview result presents the data about the customer service officers' way of talking.

"Secara umun Bapak jawab saja karyawan kita di CSI ini kan sebelum masuk di CSI sudah di tatar secara profesional dan sudah di interview degan hasil yang baik, baru bisa bekerja disni rata-rata Bapak nilai secara kesuluran mereka berkomunikasi sudah bagus karena sudah ada SOP." .."(Interviewe result from Mr. David Irwan, the Personal in Chars, $21^{\text {st }}$ of June, 2019, time: 11.44 a.m).

Base on the data above, it can be said that all of the CSI officers were qualified as the customer service officers. They had been interviewed and trained before joining to this company. In other words, they had quality in communicating either face to face or via phone call. So, the customers' complaints can be handled. Neverthelles, it was found that some CSI officers were less profesional. 
The interview result with Bpk. Dalisan as one of the Business Partner of PT. RSIM describes about the customer service officers' professionalism in communicating. Here is the data.

"Untuk kejelasan sudah jelas, tapi mereka terkadang ada groginya jika mengadapi Business Partner, groginya seperti ini, sudah jelas mereka ini orang PT, dan yang dihadapi orang Chevron jadi mereka ada persaan grogi, bukan berarti takut tapi seperti ngomong sama Bos ".(Interviwe result from Mr. Dalisan, $15^{\text {th }}$ of June, 2019, time: 11.55 a.m).

In conclusion, it was found that some CSI officers did not focus when communicating with the customers, so they did repeatation in some sentences and there was miscommunication in delivering the request to Business Partner (BP). It made wrong respon given by Business Partner toward the customers' complaints.

In the aspect of greeting, it has been appropriated with PT.Avia Jaya Indah SOP No.CSI-01/FMN, No. 4 about answering phone call procedure. It says that all of the CSI officers must greet and introduce theirselves to the customers. In fact, the researcher found that some of them miss it. This data was taken from the interview results with an employee of PT. RSIM, Ibu Fatma Roza, a PIC of PT. CPI, Bpk. Suratman, and Bpk. Didi Riyadi, a resident of Meranti Camp, No. 105

"kebanyakan CSI pagi sudah baik, kalau yang sore ada juga sih beberapa yang belum, kadangkadang harus berulang- ulang, apalagi anak baru"(Interviewe result from Mrs. Fatma Roza, a Business Partner employee of PT. RSIM, $21^{\text {ST }}$ of June, 2019, time: 10.22 a.m).

"Ada yang tidak menggunakan (greeting), mungkin dia sudah kenal dengan saya, mungkin juga sudah terlalu akrab, karena sering berhubungan dengan saya, jadi langsung halo, atau selamat pagi begitu aja". (Interviewe result from Mr. Suratman, a PIC of PT. Chevron, $21^{\text {st }}$ of June, 2019, time: 01.30 p.m).

"Kalau masalah greeting menurut saya sudah bagus, mereka memperkenalkan diri dulu siapa, kadang - kadang langsung 'hallo' gitu aja, kebetulan saya sudah sering berinteraksi kan, sudah baguslah pokoknya kalo menurut saya"(Interviewe result from Mr. Didi Riyadi, a resident of Meranti Camp, No. 105, $21^{\text {st }}$ of June, 2019, time: 10.30 a.m).

Based on the data above, it shows that some of the CSI officers did not use to greet the customer because of personal closeness with them. They tend to say "hello" to the customer even it was not appropriate with the regulation. Neverthelles, in general, they did greeting the customers profesionally.

In accordance with the problem of greeting above, the researcher clarified it to the Personal Manager of PT. Avia Jaya Indah, Mr. Ellen Elieser, SH:

"Sebenarnya kita harus membenahi itu. Jadi itulah fungsi supervisior, bagi yg tidak menggunakan greeting untuk mengingatkan karyawannya, supya lebih baik lagi, karena greeting termasuk dalam SOP walaupun CSI sudah kenal atau akrab tetap harus digunkan, (Interviewe result from Personal Manager of PT. Avia Jaya Indah, $24^{\text {th }}$ of June, 2019, time: 07.41 a.m).

From the result of interview above, it can be seen that CSI officers' greeting expression needs to be improved. So, the supervisor has to monitor and warn them for being aware to SOP.

In conclusion, customer service officers ignore the SOP in greeting the customers because of the personal closeness. Besides that, there should be an improvement of CSI officers' discipline in expressing greeting based on the SOP of PT. Avia Jaya Indah No. CSI-01/FMN No. 4 about a phone call answering procedure. So, every CSI officer has to greet and introduce her/his self to the customers in opening the talk.

\section{Gesture}

It refers to all body movements in serving the customers. In serving the customers, the customer service officers make movements to ease their job and it makes body beauty. Gesture is the basic 
indicator for the customer service officers in serving the customers directly. It is represented by facial expression, eye look, body movement, mouth movement, and way to walk.

Several interview results present the data about customer service officers. First is the interview with a business partner's employee namely Mr. Anto from PT. INCA Rumbai. He often visits the customer service officers' office.

"Kalau kita kan berbeda dengan bank, kalau kita di sini kan bekerja saling membutuhkan, kita customer membutuhkan CSI, CSI membutuhkan kita, ya biasa aja, ketika kita masuk kita ucapkan salam, dijawab sama kawan CSI dengan baik, ya cukup baguslah"(Interviewe result from Mr. Anto, a business partner employee, $17^{\text {th }}$ of June, 2019, time: 08:23 a.m).

From the above interview result, it can be seen that there was a teamwork relationship between CSI officers and business partner employees so they had served the other companies well.

Then, the interview result from Mr. Guntoro, an employee of PT. RSIM.

"Setiap BP yang datang dalam pengurusan dokumen ke Helpdesk kadang tidak ada CSI yang datang menyambut atau menyapa bertanya pada BP tersebut terlebih dahulu mungkin sibuk kerja atau karena hal lain, harusnya ada CSI stand by yang stand by di depan, karena ada BP baru yang tidak mengerti alurnya." (Interviewe result from Mr. Guntoro, an employee of PT. RSIM, $21^{\text {st }}$ of June, 2019, time: 09.03 a.m).

The result of interview shows that there was no CSI officer welcomes the business partner employee because they were in a phone call or doing some other works. Whereas, there should be a customer service officer greet the guests.

This following is the interview result with a new business partner employee. He did not know about the administration compiling procedure and everything relates to the customer service officers.

"Untuk yang berkunjung ke kantor Help Desk ya, saya melihat tidak ada front line nya, kayak bank gitu, kayak teller gitu ya, yang menyambut kita, kalo di kantor Help Desk saya lihat semuanya sibuk kerja masing-masing, tidak ada yang menyambut customer di kantor, kan kerja Help Desk ndak hanya mengangkat telpon aja, juga menghandle dokumen, invoce invoce dari BP, tiap BP datang tidak ada sambutan dari Help Desk, karena kadang BP itu BP baru, jadi ndak ngerti apa yang harus dilakukan"'(Interviewe result from Mr. Fadli, a business partner employee of PT. RSIM, 20 ${ }^{\text {th }}$ of June, 2019, time: 04.26 p.m).

Interview result above describes that there should be a standby CSI officers to greet the customers so the service implementation can be improved. So, if other customers come, they had not need to wait.

Based on the data above, the researcher sees that the CSI officers had good gesture in implement the service to the customers. Unfortunately, the customers who wanted to compil the administration had to wait so long for the CSI officers' service due to many requests coming. It was caused by no standby customer service officers to greet the customers.

In conclusion, the CSI officers' gesture generaly was good. It was appropriated to PT. Avia Jaya Indah SOP No. CSI-01/FMN, No. 2 about a phone call answering procedure. It will be better if there was a standby customer service officer to greet the customer.

\section{Asking Question}

It is a way of people to clarify a clarity, affirmation, and certainty about a thing. In this research, asking question defines as the customer service officers' way in getting the customers' clarity or cconfirmation about unclear or less information especially complaints given by them.

Every customer service officers of PT. Avia Jaya Indah must have a good way of asking questions although their education background is opposite to the customers' complaints. It was due to wide area of working. So, the complaints can be accepted, understandable, and having effective and efficient response. 
The indicators for asking question are attitude in questioning, language choice, and intonation. The researcher found that generaly the customer service officers were good and professional. It is proved by the following interview results.

"Mereka intonasinya tidak keras, saya rasa mereka profesional, karena mereka menjawab dengan lembut, dengan ramah tamah, cara bertanya baik, yang saya alami mereka belum pernah melakukan hal itu ( menyinggung perasaan), saya rasa mereka baik dalam menggunakan bahasa tersebut, kadangkadang saya sebagai user juga mengkonfirmasi mereka, ketika ada keluhan saya, yang saya belum pahami , misakan alat atau tindakan yang akan diperbaiki, atau ada yang rusak"(Interviewe result from Mr. Asep Salam, the PIC of PT. CPI, $21^{\text {St }}$ of June, 2019, time: 03.23 p.m).

It can be seen that the CSI officers were professional in asking question and implementing ethical services. They were good in choosing language and using intonation.

"Sejauh ini, mungkin karena saya sering berhubungan dan mungkin juga sudah sering, ya mereka bagus, bukan karena ada kepentingan, saya hanya berbicara jujur aja." (Interviewe result from Mrs. Endri Yasni, BP employee of PT. CPI, $29^{\text {th }}$ of May, 2019, time: 10.47 a.m).

It presents that the CSI officers were good in asking question. The intonation used and language choosen were standard. But, researcher found that there was a CSI officer confused in asking question and responding customers' complaints related civil engineering field work.

It goes along with Mr. Yulizar, a business partner employee of PT. RSIM interview result below.

"Masih baik (pemilihan bahasa), tetapi perlu ini pelatihan-pelatihan lagi, karena ini kaitanya dengan rumah, yang notabene pekerjaan sipil, CSI sendiri rata-rata cewek yang backgroundnya bukan disana, sehingga masih taraf penyesuaian dan pembelajaran, dan proses waktu yang menentukan mereka profesional kedepannya." (Interviewe result with Mr. Yulizar, a business partner employee of PT RSIM, $21^{\text {st }}$ of June, 2019, time: 09.15 a.m).

The result of interview shows that although the language use were good, there should be a training relates to the knowledge of workfield because almost of CSI officers are women who do not know about it.

Researcher interviewed the CSI officers' supervisor to get supporting data. Here is the result of the interviewe.

"Pada dasarnya seluruh karyawan CSI yang bekerja di PT Avia Indah jaya sudah dibekali dengan pelatihan - pelatihan, untuk menerima telpon atau permintaan customer, jadi seyogyanya mereka sudah paham dengan kata sambutan awal, atau cara bertutur kata dengan seluruh karyawan Chevron ini." (Interviewe result from Mr. Erwan., S.Kom, the CSI supervisor of PT. Avia Jaya Indah, $21^{\text {st }}$ of June, 2019, time 02.28 p.m).

It can be seen that the CSI officers generally were good in asking question. It was based on the SOP of CSI-01/FMN, No. 4 about how to make a phone call because they had trained related to the job descriptions.

From six indicators of customer service officers' ethic, the obstacle found in indicators of dressing relates to the uniform and way of talking. It can be proved from the interview results above.

\section{B. Obstacles in Improving the Customer Service Officers Ethic of PT. Avia Jaya Indah at PT. CPI Pekanbaru}

Customer service officer is the image representative of a company. Even though every job description has a Standard Operational Procedure (SOP), there were obstacles found in service implementation process. They are:

1. The lack of professionalism in communicating between CSI officers and PT. CPI employees due to personal closeness. 
2. The lack of direct follow up conducted by the CSI officers so the customers hard to know the progress of their requests.

3. The lack of CSI officers' capability in mastering the work field so they hard to describe it to customers.

4. The lack of daily evaluation of CSI officers' work done by supervisor so there was no direct correction for the current mistaken. It makes the complaints from customers were late to process.

5. The lack of reward and punishment given formarly, clearly, and structured. It makes the officers become neglectfull.

\section{CONCLUSION}

Based on the finding of the research, the researcher states some conclusion. They are:

1. Generaly, the CSI officers' ethic of PT. Avia Jaya Indah were qualified and appropriate with the indicators determined. Unfortunately, there are some weaknesses found such as no greeting expressed by few CSI officers, some of them did not wear uniform, and some officers had lack of professionalism in responding customers' complaints because less of information and understanding relates to work fields.

2. CSI officers had lack of professionalism in communicating with the customers, there were no follow up relates to the customers' complaints because they had less of information and understanding relates to work fields and there was no daily evaluation of CSI officers' work done by the supervisor.

\section{SUGGESTION}

Pertaining to the findings of the research, the researcher provides some following suggestion. They are:

1. There should be a periodicaly and continuous training given to the CSI officers to improve their capability in providing service. So they are able to follow the rule naturaly.

2. There should be a reward given to improve the CSI officers' spririt.

3. Renewal the uniform periodicaly. So there was no employee wear non-uniform clothing because of tight, broken, etc.

4. There should be a periodicaly evaluation neither their discipline nor service-excellent giving.

5. Improving the CSI officers' professionalism in giving information to customers relates to the work field in order to avoid miscommunication.

6. There should be an evaluation relates to the CSI officers' uniform given by the personal manager in order to support them to wear the uniform.

\section{BIBLIOGRAPHY}

[1]. Anggara Sahaya, 2012, Ilmu Administrasi Negara, Pustaka Setia, Bandung

[2]. Bertens. 2000. Etika. Jakarta: Gramedia Pustaka Utama. 
[3]. Fathoni, Abdurrahmat. 2006.Organisasi Dan Manajemen Sumber Daya Manusia. Jakarta: PT Rineka Cipta.

[4]. Gronroos, Christian. 1990. Service Management and Marketing: Managing the Moment ofTrust in Service Competitio.Tronto: Lexington Books

[5]. Hasbuan (2003:244) Manajemen: Dasar, Pengertian, dan Masalah . Jakarta: Bumi Aksara.

[6]. Kasmir.2011. Etika Costumer Service.Jakarta:PT. Raja Grafindo Persada

[7]. Kamus Besar Bahasa Indonesia (KKBI, edisi ke 1, 1998) yang dikutip oleh K.Bertens (2011:5)

[8]. Keputusan Menteri Negara Pendayagunaan Aparatur Negara (Meneg PAN) Nomor 63/KEP/M.PAN/7/2003

[9]. K, Betens. Etika:Jakarta,Gramedia Pustaka Utama 2011

[10]. Kotler, P., \& Rubin David S. Statistic of Management 7th Edition (New Jersey: Prentice Hall inc., 1998

[11]. Muchlas, Makmuri. 2008. Perilaku Organisasi. Gadjah Mada University Press: Yogyakarta.

[12]. Pasalong Hasibuan,2013, Teori Administrasi Publik, Alfabeta, Bandung

[13]. P. Siagian, Sondang. 2006. Manajemen sumber daya manusia. Jakarta : Bumi aksara

[14]. Sadili, Samsudin. 2006. Manajemen Sumber Daya Manusia. Bandung : Pustaka Setia.

[15]. Saffie, Inu Kenacana,2011, Pengantar Manajemen, Erlangga, Jakarta

[16]. Sedarmayanti. (2011).Manajemen Sumber Daya Manusia, Reformasi Birokrasi dan Manajemen Pegawai Negeri Sipil (cetakan kelima). Bandung : PT Refika Aditama

[17]. Soewarno Handayaningrat. 1996 Pengantar Studi Ilmu Administrasi dan Manajemen: Jakarta. Gunung Agung

[18]. Terry, George R. Publisher.2012. Prinsip Management. Jakarta : Bina Aksara.

[19]. Tim Depdiknas. 2005. Kamus Besar Bahasa Indonesia.Jakarta: Balai Pustaka.Hlm.849.

[20]. Veithzal Rivai, 2011, Manajemen Sumber Daya Manusia untuk Perusahaan, Bandung: PT. Remaja Rosda Karya.

[21]. Wijaya, Indra. 2012. Perilaku Organisasi. Bandung : Sinar Baru Algensindo

[22]. Wursanto. 2010. Dasar-Dasar Ilmu Organisasi. Yogyakarta : Andi.

P-ISSN 1693-3516 | E-ISSN 2528-7575 